Volume 13 Number 4, October-December 2019: pp. 381-406. Copyright (c) 2019 FIAT JUSTISIA. Faculty of Law, Lampung University, Bandarlampung, Lampung, Indonesia. ISSN: 1978-5186 | e-ISSN: 2477-6238. Open Access: http://jurnal.fh.unila.ac.id/index.php/fiat

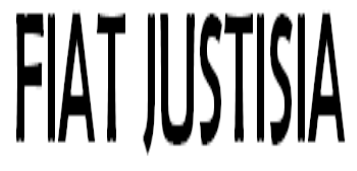

Fiat Justisia is licensed under a Creative Commons Attribution 4.0 International License, which permits unrestricted use, distribution, and reproduction in any medium, provided the original work is properly cited.

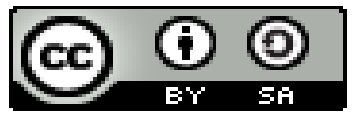

\title{
Legal Responsibility in the Pollution and Environmental Destruction Due to Gold Mining Exploitation in Botak Mountain of Buru Regency
}

\author{
La Ode Angga \\ Universitas Pattimura, Ambon, Indonesia \\ laodeangga@yahoo.com \\ Hasan Suat \\ Universitas Pattimura, Ambon, Indonesia \\ hasansuat34@gamail.com
}

\begin{abstract}
From the case of environmental destruction and pollution that occurred in Buru Island, Maluku Province, the principle of civil liability or known as "obligation" or "aanspraakelijkheid" can be used for those who need assistance to the community and can be used for the principle of accountability. In the case of environmental destruction and pollution that occurs on Botak Island, Buru Mountain, the miners used mercury and cyanide to process minerals in obtaining gold. Based on Article 87 paragraph (1) UUPPLH, the obligation from this pollution can be qualified for the fulfilment of violation, including (a) committing an unlawful act; (b) The presence of environmental pollution and or damage; (c) cause harm to other people or the environment; and $(d)$ is a responsibility and/or activity. Furthermore, to be able to fulfill the compensation according to civil law, Article 1365 of the Civil Code requires the existence of a onrechtmatigedaad or acts against the law, which contains: (a) the act violates the law; (b) the action is based on mistakes; (c) the consequences of these consequences;

Article 1365 of the Civil Code can indeed protect one's rights because a party has suffered from the actions of others that cause these disadvantages. Therefore, it is assumed that being against the law here outlines the existence of rights and obligations when committing an act, either an error or
\end{abstract}


negligence or also injuring another person, and resulting in arising from other people.

Keywords: Environmental, Pollution, Responsibility

How to Cite: La Ode Angga, Hasan Suat, "Legal Responsibility in the Pollution and Environmental Destruction Due to Gold Mining Exploitation in Botak Mountain of Buru Regency”, Fiat Justisia, 13 (4), (2019).

DOI: 10.25041/fiatjustisia.v13no4.1695

\section{A. Introduction}

The 1945 Constitution of the Republic of Indonesia (Undang-Undang Dasar NKRI 1945), further stated as the 1945 Constitution, mandated the government, employers and elements of the society to execute the environmental protection and management. This includes natural resources, in the implementation of sustainable and environmental development. ${ }^{1}$ The provisions of Article $28 \mathrm{H}$ paragraph (1) and Article 33 paragraph (4) of the 1945 Constitution are basic norms in the protection and management of the environment in Indonesia. Article $28 \mathrm{H}$ paragraph (1) states:

"Everyone has the right to live in physical and spiritual prosperity, to live, and to get a good and healthy environment and the right to receive health services". Furthermore, in Article 33 of the 1945 Constitution, specifically paragraph (4) states: The national economy is organized based on economic democracy with the principle of togetherness, fair efficiency, and sustainable, environmentally sound, independent and by maintaining a balance of progress and unity of the national economy".

The State's (Indonesia) right to control the field of environmental protection and management in Indonesia ${ }^{2}$ is implemented by the Government of the Republic of Indonesia with the approval of the People's Representative Council of the Republic of Indonesia through the Law No. 32 of 2009 concerning Protection and Management of the Environment, here in after referred to as UUPPLH, (State Gazette of the Republic of Indonesia No. 140, Supplement to the State Gazette of the Republic of Indonesia No. 5059).

\footnotetext{
${ }^{1}$ Helmi, Hukum Perizinan Lingkungan Hidup, Jakarta: Sinar Grafika, (2012), p. 1.

${ }^{2}$ La Ode Angga, "Prinsip Kehati-Hatian Dalam Peraturan Daerah Rencana Tata Ruang Wilayah Provinsi Maluku Di Bidang Pengawasan Dan Evaluasi Berbasis Keberlanjutan Lingkungan Hidup", Disertasi Universitas Brawijaya, (2015), p. 5.
} 
Furthermore, the Government of the Republic of Indonesia with the approval of the People's Representative Council of the Republic of Indonesia has enacted Law No. 4 of 2009 on Mineral and Coal Mining, (State Gazette of the Republic of Indonesia No. 4 Supplement to the State Gazette of the Republic of Indonesia No. 4959). In Articles 64 and 65 of the Mineral and Coal Mining Law, regulates mining business licensing requirements:

Article 64

The government and regional government by their authorities are obliged to announce plans for mining business activities in areas, with Mining Permit ${ }^{3}$ as intended in Article 16 and Provide Exploration Mining Permit and Mining Production Operation Permit as referred to in Article 36 openly to the public.

\section{Article 65}

(1) Business entities, cooperatives, and individuals as meant in Article 51, Article 54, Article 57, and Article 60 which carry out mining business must fulfill administrative requirements, technical requirements, environmental requirements, and financial requirements.

(2) Government regulations regulate further provisions regarding administrative requirements, technical requirements, environmental requirements, and financial requirements as referred to in paragraph (1).

The empirical reality is the exploitation of the gold mine on Buru's Botak (bald) Mountain, which has caused serious and significant environmental destruction and pollution. It began in 2011, where residents found gold on the Gunung Emas or Golden Mountain, another name for Botak Mountain. At that time, the community immediately extracted gold from Botak Mountain, using temporary equipment. The situation changed after advanced equipment arrived to process the gold. Initially, residents of Buru Island only used kitchen utensils such as nyiru, pots and pans to gain gold. When more modern tools are brought in from outside the area to Gunung Emas, manual methods as mentioned above are no longer used. ${ }^{4}$

Miners, which were only about hundreds of people, have now doubled to tens of thousands of people. In addition to residents, miners from various regions such as Kalimantan, Makassar and Java, also came to Buru Island to hunt for gold. Since then, various levels of mining have sprung up in this location, ranging from entrepreneurs, miners, gold processors, traders, and others. Gambling and circulation of liquor to drugs are also prevalent at the

\footnotetext{
${ }^{3}$ In Indonesian legal terms stated as Wilayah Izin Usaha Pertambangan (WIUP).

${ }^{4}$ http://www.mongabay.co.id/2018/06/10/petaka-tambang-emas-di-pulau-buru/, accessed on August 14, 2018.
} 
mine site. Stolen and cyanide is allegedly used in the mining system. Although many times the government tried to take actions, there were still available locations for the miners to perform illegal activities. These ill factors have created pollution around the environment in a serious and significant damage level. Moreover, resident's livestock and personal pets suddenly expired in high numbers. This was allegedly due to mercury and cyanide waste being used in this location recklessly as it scattered and flowed into the rivers leading to the Sea of Buru Island.

In anticipation of not getting sick because of mercury and cyanide pollution, residents no longer consume vegetables and water around the Gunung Emas. ${ }^{5}$ There was an increase of damage since March 2018 where around 1,000 more tents and immersion ponds owned by miners at that location were polluted. These ponds that belong to several entrepreneurs are not only in the plateau but also the lowlands of Botak Mountain. ${ }^{6}$

Based on the description above, problems in this study are formulated as, what is the form of legal liability in the environmental pollution and destruction due to the exploitation of gold mines in Botak Mountain of Buru Regency according to Law Number 32 of 2009 ?

\section{B. Research Methods}

The research type is a normative legal research. This research focuses on the object of study that includes the provisions of legislation and legalmaterial documentaries. The subject matter is the legal liability in the case of pollution and environmental destruction due to the exploitation of the gold mining in Botak Mountain of Buru Regency based on Law Number 32 of 2009. This study will explore, collect, compare, explain and analyze legal facts contained in the articles of the 1945 Constitution, Undang-Undang Pokok Agraria (UUPA) or the Law of Basic Agrarian, UUPPLH and the Law on Mining. It also uses several approaches. The approach will use questionnaires technique and researchers obtain information on various aspects of the issue through reviewing these answers. Additionally, this research uses statutory approach ${ }^{7}$ and conceptual approach. ${ }^{8}$

\section{Discussion}

\footnotetext{
${ }^{5}$ Ibid.

${ }^{6}$ Ibid.

${ }^{7}$ Theory Hutchinson, Reseaching and Writing in Law, Australia: Lawbook Co, Pyrmon NST 2009, (2002), p. 55.

${ }^{8}$ Peter Mahmud Marzuki, Penelitian Hukum, Jakarta: Kencana Prenada Media Group, (2008), p. 93.
} 


\section{Definition of the Environment}

Environment is a combination of physical conditions that include the state of natural resources such as land, water, solar energy, minerals, and flora and fauna that grow on land and in the ocean, with institutions that include policies in managing the physical environment. The environment or "lingkungan hidup" in Indonesia is often also called as the "lingkungan" as stated in the Law No. 32 of 2009 concerning Environmental Management. ${ }^{9}$

The definition of environment is the unity of space with all objects, power, circumstances, and living things, including humans, and behavior, which affects the survival of life, the welfare of humans and other living things which affect their lives. Understanding the environment can be said as everything that exists around humans or living things that have reciprocal and complex relationships and influence each other between one component and other components. According to the Law No. 32 of 2009, the Environment is the unity of space with all objects, power, circumstances, and living things, including humans and their behavior, which affects the survival of life and the welfare of humans and other living beings. The scope of the Indonesian environment includes areas of the Republic of Indonesia that carries out sovereign rights and jurisdiction. The law No. 32 of 2009 states that protection and management of the environment are systematic and integrated efforts carried out to preserve environmental functions and prevent the occurrence of pollution and environmental damage which includes plans, utilization, control, maintenance, supervision and law enforcement.

The law No. 32 of 2009 states that the definition of environmental pollution is the entry or inclusion of living things, substances, energy, and/or other components into the environment by human activities so that they exceed the prescribed Environmental Quality Standards. On the other hand, the definition of environmental destruction is the act of people who cause direct or indirect changes to the physical, chemical and/or biological properties of the environment so that they exceed the standard criteria for environmental damage.

\section{Form of Legal Liability in Environmental Pollution and Destruction Due to Gold Mining Exploitation in Botak Mountain of Buru Regency Based on Law Number 32 of 2009}

In the last few years of Buru Island, Maluku Province, there has been a form of exploitation of the environment that is quite large, mostly in Botak Mountain where this activity has claimed lives, properties and even the

\footnotetext{
${ }^{9}$ http://www.artikellingkunganhidup.com, accessed on February 18, 2019.N.H.T Siahaan, Hukum Lingkungan dan Ekologi Pembangunan, Jakarta: Erlangga, (2004), p. 4.
} 
environment. This exploitation is related to illegal mining of gold which is estimated to have a large content. According to a report by the Baileo Maluku Non-Governmental Organization, illegal mining of gold in Botak Mountain is very alarming, because in addition to the effects of chemical use and environmental destruction, it has also caused conflict between residents, especially between residents and miners.

From several reports released by print media in Maluku, until October 2012 alone, the value of money that had been circulating for the purchase of gold had reached approximately more than 365 trillion Indonesian Rupiah. This money is used by miners and the local people themselves. ${ }^{10}$ The amount is certainly fantastic if seen from the management perspective because it is very contrary with the lives of Buru Islanders who have so far relied more on eucalyptus oil and fishery business. Viewed from the aspect of environmental management, this certainly needs to be addressed wisely and wisely.

The Maluku Provincial Government and the Buru Regency Government in particular, have indeed made various efforts to handle it, ranging from mining restrictions, site closure, returning miners from outside the area. However, this did not impact effectively. In 2013, the mining activities were already crowded again until this day, and it is estimated that local officials supported the activity.

Regarding this, the Maluku's Provincial Health Engineering Center or Balai Kesehatan Teknik Lingkungan (BTKL) in collaboration with the their Provincial Health Office or Dinas Kesehatan (Dinkes) have conducted a water sample test in response to environmental pollution due to gold mining activities, and from the results of the tests, it was found that there were a number of clean water points and rivers in the area around the mine which is also contaminated with mercury metal. ${ }^{11}$ It is feared that if mining is carried out again, the effects of "mercury" and "cyanide" must be concerned, especially since illegal mining is considered a custom by using traditional tools without permit from the entitled authority.

From the perspective of environmental law enforcement, the pollution cases completion require 3 (three) legal approaches including administrative environmental law, civil environmental law, and criminal law environment. This is reasonable; given the position of environmental law itself is a

\footnotetext{
${ }^{10}$ Harian Pagi, Ambon Express, published on October 10,(2012).

${ }^{11}$ Harian Pagi "Siwalima", edition January 17,(2013). It has been reported that the mercury content has reached $0.0529 \mathrm{mg} /$ liter on Waepo River, $0.0049 \mathrm{mg} /$ liter on Suket River, 0.0089 $\mathrm{mg} /$ liter in Nekat River, $0.006 \mathrm{mg} /$ liter in Wamsait River, $0.0042 \mathrm{mg} /$ liter at Anahoni River da $0.0463 \mathrm{mg} /$ liter in Hulu Wamsait River, which is a community activity.
} 
functional law. However, the interesting issue is how the civil liability law is concerned with environmental pollution that occurs on Botak Mountain. ${ }^{12}$

According to Sundari Rangkuti, ${ }^{13}$ civil environmental law aims to provide legal protection for victims of environmental pollution by submitting a dispute in the public court. Settlement of environmental dispute is intended as a claim for compensation based on illegal actions in the field of civil environmental law by victims of environmental pollution.

Article 84 paragraph (1) of the Law Number 32 of 2009 concerning Protection and Management of the Environment, from now on abbreviated as UUPPLH, affirms that the settlement of environmental disputes can be reached through court (litigation) or without court (non-litigation). In paragraph (2), it stated that the choice of environmental dispute resolution is carried out voluntarily by the parties to the dispute. Paragraph (3) stated "A lawsuit through a court can only be taken if an attempt to resolve a dispute outside the chosen court is declared unsuccessful by one of the parties to the dispute". ${ }^{14}$ Regarding to this environmental dispute, the government has provided a Service Provider Institution to Resolve Environmental Disputes outside the Court based on Government Regulation No. 54 of 2000.

By revisiting the case of environmental pollution that is increasingly claiming the lives of the people of Buru Island, Maluku Province, it is interesting to study it from the perspective of the principle of civil liability in the case of the environment. Because so far, the community is confused and does not know whether the recovery of their civil rights as victims of an environmental pollution due to illegal mining by miners could be restored or not. And if it is possible, how is the fulfillment of those rights from the perspective of civil liability.

In Black's Law Dictionary, "liability" has a broad scope of understanding, which includes: $:^{15}$

a. An obligation one is bound to the law or justice;

b. Condition of being responsible for actual loss;

c. Condition which creates a duty to perform action immediately in the future.

From the scope of such understanding, it is assumed that the actual definition of responsibility is very broad. What about legal responsibility.

\footnotetext{
${ }^{12}$ Siti Sundari Rangkuti (I), "Inovasi Hukum Lingkungan: Dari Ius Constitutum ke Ius Constituendum", Speech of Inauguration of Professors said at the Senate Meeting of Airlangga University, Faculty of Law, Universitas Airlangga, Saturday, May 11, (1991),p. 5.

13 Siti Sundari Rangkuti (II), Hukum Lingkungan dan Kebijaksanaan Lingkungan Nasional, EdisiKetiga, Surabaya: Airlangga University Press, (2005), p. 265.

${ }^{14}$ La Ode Angga, "Alternatif Penyelesaian Sengketa Lingkungan Hidup di Luar Pengadilan (Non Litigasi)", Jurnal Ius (Jurnal Kajian Hukum dan Keadilan), 6 (2), (2018), p. 3.

${ }^{14}$ M. Chief, Black’s Dictionary, St Paul Minessota: Mwest Group, (2000), p. 739.

${ }^{15}$ Ibid.
} 
According to the Black Law Dictionary, "legal liability" means "liability which is recognized and enforced between parties litigant". With that stated, legal responsibility is a responsibility that is recognized and enforced by the court between the parties who litigate.

From this assumption, it is stated that the responsibility in the civil law exists, if there is an agreement as stipulated in Book III of the Civil Code. Generally, civil law experts argue that the source of the engagement as formulated in Article 1233 of the Civil Code is incomplete because besides there are also recognized doctrines, unwritten laws and judges' decisions. ${ }^{16}$ More explicitly, if described in the provisions of Article 1233 of the Civil Code, there are 4 (four) important elements, namely: ${ }^{17}$

\section{a. An existing legal relationship}

In a legal relationship there is an inherent "right" on one party and "obligation" on the other. If one party does not pay attention to or violate the relationship, then the law will force the legal relationship to be fulfilled or restored.

\section{b. Wealth}

Even though legal relations are not solely valued by money, and if society and a sense of justice require that a legal relationship be given legal consequences, then the law will put the effect on the relationship as an agreement.

\section{c. Parties}

Generally, in legal relations, there are 2 (two) or more parties, namely who have the right to achievement and those who must fulfill their achievements.

\section{d. Achievement}

Achievement as result of a negotiation is the core of an agreement because if the parties have fulfilled the achievements, the agreement ends.

Article 1233 of the Civil Code also confirms that an agreement can be born from a negotiation and law. It was said to be born and sourced from the agreement because it was indeed wanted by the parties, while it was born because of the law because of the will of the legislators and beyond the will of the parties. ${ }^{18}$ Associated with liability, it is assumed that the definition of liability itself is a new term that develops with the intention of holding someone accountable because of negligence which causes harm to other parties, especially the lawsuit against civil rights that occur in the field of civil law.

\footnotetext{
${ }^{16}$ Mariam Darus Badruzalman, Kompilasi Hukum Perikatan, Bandung: Citra Aditya Bakti, 2001, p. 9.

${ }^{17}$ Ibid, pp. 1- 6.

${ }^{18}$ Subekti, Hukum Perjanjian, Jakarta: Intermasa, Cetakan XVIII, (2001), p. 1.
} 
Rossa Agustina ${ }^{19}$ explained that the form of accountability in civil law could be grouped into two parts; contractual and liability. Accountability is for illegal acts. The difference between contractual responsibility and liability is whether or not in the legal relationship there is an agreement. If there is an agreement, then the responsibility is contractual. While if there is no agreement, but one party harms the other party, the aggrieved party can sue the detrimental party responsible based on illegal acts.

It can be stated that the actual liability is related to the existence of a lawsuit in the field of civil law, where certain parties (defendants) are asked to bear the claim of another party, which claim occurs as a consequence of a reaction to a damage suffered by the other party (the plaintiff).

From such assumptions, in a responsibility there are two parties, in which one is obliged to be responsible for the damages incurred to the other party. Thus, several key elements can be stated, namely:

a. There is a damage experienced by the plaintiff. Damages are the cause of the arising of the claim by the party who feels disadvantaged.

b. There is an act of the person (defendant) that causes harm.

c. There is a claim from the injured party. The claim was intended to request that the damages suffered by the defendant.

In line with the thoughts above ${ }^{20}$ Moegni also stated that the term defenders described the existence of aansprakeleijkheid, which emphasizes the accountability of an offender. The perpetrator then must be responsible for his actions, and because of that responsibility, the perpetrator must be held accountable in the claim filed in front of the court by sufferers.

In civil law, a liability is recognized for someone's new deed, if the person commits an act which is not permitted by law and most of the acts referred to constitute an act which in the Civil Code is called an illegal act (onrechtmatigedaad). The development of civil law recognizes several types of liability:

\section{a. Contractual Liability}

This type of liability arises because of a breach of promise that is not carrying out an obligation (achievement) or not fulfilling the rights of another party as a result of a contractual relationship. This type of liability is not based on the existence of contractual obligation, but for illegal acts (onrechtmatigedaad). Therefore, understanding against the law is not only limited to actions that are contrary to the law, both against one's own legal obligations and other legal obligations, but also contrary to morality and

\footnotetext{
${ }^{19}$ Rossa Agustina, dkk, Hukum Perikatan (Law Obligation), Seri Unsur-Unsur Penyusun Bangunan Negara Hukum, Denpasar Bali: Pustaka Larasan, (2012), p. 4.

${ }^{20}$ Moegni Djojodirjo, Perbuatan Melawan Hukum, cet I, Jakarta: Pradnya Paramita, (1979), p. 113.
} 
contrary to accuracy that should be done in the life of others or people others (Decision of Hogeraad, January 31, 1919).

The concept of liability in tort comes from Article 1382 of the Napoleontic Civil Code, "Everyone causes damages through his own behaviour must provide compensation, at least the victim can prove a causal relationship between the fault and damages". This concept is in line with Article 1365 of the Civil Code that: "Any act that violates the law that brings harm to another person requires the person who caused the loss because of his mistake to compensate for the los".

\section{b. Strict Liability}

This type of liability is often referred to as a liability without fault, ${ }^{21}$ considering that a person must be responsible even though he has done nothing wrong, whether intentional, recklessness or negligence. Such liability usually applies to product sold or article of commerce, where producers must pay compensation for the catastrophe caused by the product they produce unless the manufacturer has warned against the possibility of such a risk. In the development of strict liability it is also known as the principle of absolute responsibility (no-fault liability or liability without fault) which in the library is known as the principle of responsibility without having to prove the existence of errors.

Factors at least influence the development of strict liability towards responsibility based on errors: ${ }^{22} 1$ ) Moral Philosophy or moral reasons derived from religious teachings that developed at that time. This reason then encourages the recognition of moral errors as the right basis for determining criteria for illegal acts. 2) Developments among the public that negligence can also be a factor that determines the loss of other parties, in addition to the element of intent. So here it is implied that initially strict liability only recognizes errors in the form of intentions.

\section{c. Vicarious Liability}

This type of contrarian arises due to errors made by subordinates. This type of responsibility is an extension and deepening of the regulative principle of the judicial and moral aspects, namely in certain cases a person's

\footnotetext{
${ }^{21}$ This term was originally known through the concept of "absolute liability", which was first used by John Salmond in his book The Law of Tort, in 1907, while the use of "strict liability" was put forward by W.H. Wiinfield in 1926 with a well-known article, The Myth of Absolute Liability, in Wiradipradja Saefula, Responsibility of Carriers in International and National Transport Law, Yogyakarta: Liberty, 1989, p. 35 See also Muladi and Dwidja Priyatno, Corporate Criminal Responsibility, cet III, Bandung: Kencana Prenada Media, Group Revised (2012) Edition, p. 111.

${ }^{22}$ Saefula, Op.Cit., p. 18.
} 
responsibility is deemed to be extended to the actions of his subordinates who commit acts for him or within the limits of his orders.

From the explanation above it becomes clear that in terms of its form, there are two forms of liability, namely the liability for damages caused by default, and the liability for losses caused by acts against the law as emphasized by Rosa Agustina above. Thus, civil liability aims to obtain compensation for losses suffered, in addition to preventing the occurrence of things that are not desirable. The basis requires that the defendant who is deemed to have harmed another person regarding acts against the law or default gives the right to the aggrieved person to receive compensation from another party who has an obligation to the party suffering from the damage.

\section{d. Accountability in the Environment Case}

It no longer needs to be covered anymore that the environment in Indonesia suffers quite seriously. But in this case, Indonesia and the international world continue to make efforts and understand the urgency of the need to restore environmental quality to preserve the present life without endangering the prospects of future generations.

Building a solid future from environmental aspects certainly requires sharp vision and shared commitment. The future momentum will be a day filled with several achievements to reach an ecologically healthy global society, largely determined by a sense of appreciation for the environment. ${ }^{23}$ Ironically, the "portrait" of pollution and environmental destruction appears uncompromising and often extends endlessly with a series of complex consequences.

Judging from a juridical perspective, pollution and environmental damage have been qualified as environmental conflicts. That is, pollution and environmental destruction determine the level of escalation and the existence of environmental disputes. Article 1 (25) of Law Number 23 of 1997 concerning Environmental Management (UUPPLH) which was subsequently refined by Law Number 32 of 2009 concerning Environmental Protection and Management (UUPPLH), formulates "Environmental disputes as disputes between two parties or more arising from activities that have the potential and / or have an impact on the environment"

It can be understood that environmental disputes contain conflicts or controversies in the field of environment, which are interpreted as "dispute a conflict or controversy", "a conflict of claims or rights", "an assertion of right, claims, or demand on one side", "met claims by allegations on the other". The

${ }^{23}$ Lester R. Brown, Dua Puluh Dua Segi Masalah Kependudukan, Jakarta: Yayasan Obor Indonesia, (1992), p. 22. 
terminology of "dispute settlement" itself has other references such as "dispute resolution", 24 "conflict management", "conflict settlement", "conflict intervention". 25

Generally, in a dispute, it is accepted that environmental disputes do not arise solely from disputes between parties but also disputes accompanied by "claims". It is certainly reasonable because demands are the primary attribute of the existence of a dispute. Thus, the formulation of Article 1 number 25 UUPPLH only means environmental disputes or "disputes between two parties or more" without stating the existence of "claim". The basic problem is who the conflicting parties are in an environmental dispute, who is the subject of the environmental dispute, or who is disputed.

UUPPLH does not provide definitive answers to anyone who is the subject of an environmental dispute. However, by using the method of interpretation in law, it is assumed that the subject of environmental disputes is the disputing parties who are disadvantaged due to an ill development of the environment.

From the explanation above, disputes occur because certain parties are disturbed by the other party. Therefore, these parties reclaim their rights or ask for their interests to be restored by those who caused the damage. If we look at such assumptions, there are actually 2 (two) main things that can be found in the conflict or dispute, namely (a) the existence of a violation of the interests of others, and (b) the existence of claims or demands or in the perspective of civil law known as the technical term, "lawsuit".

In a position of conflict or dispute, both parties are in a position to face each other. Therefore, the two main points above are elements that are "cumulative" for the emergence of disputes. In other words, disadvantaged parties without demands are not considered as a conflict, and this is certainly seen from the view of the community as injustice. Therefore, the conflict will only occur if the disputing parties are in a position to oppose each other to defend their interests.

UUPPLH, Article 84 paragraph (1) to paragraph (3) states that dispute resolution can be made through (a) court lines or outside the court, (b) the choice of environmental dispute resolution is carried out voluntarily by the parties to the dispute, and (c) a claim through a court can only be taken if an attempt to resolve a dispute outside the chosen court is declared unsuccessful by one of the parties to the dispute. Particularly concerning environmental disputes through the courts (litigation), the process includes, (a) compensation

\footnotetext{
${ }^{24}$ Henry Campbell Black, Black'a Law Dictionary, St. Paul, Minn: West Publishing Co, (1991), p. 327.

25 LutfiYazid, Penyelesaian Sengketa Lingkungan (Environmetal Dispute Resolution), Surabaya: Airlangga University Press - Yayasan Adikarya IKAPI - Ford Foundation, (1999), p. 9.
} 
issues (Article 87), (b) absolute responsibility (Article 88), and (c) expired to file a lawsuit (Article 89).

Affirmed in the law, dispute resolution through the court can be taken if the dispute resolution without court is unsuccessful. Explicitly, the aspect of civil law in the case of environmental disputes is obtained through the obligation to pay compensation or certain actions as confirmed in Article 87 of the UUPPLH that:

1) Every person in charge of a business and/or activity which violates the law in the form of environmental pollution and/or damage which causes harm to another person or the environment must pay compensation and/or take certain actions.

2) Any person who transfers alters the nature and form of business, and/or activities of a business entity that violates the law do not give up legal responsibility and/or obligations of said business entity.

3) The court can determine the payment of forced money on every day of delay in the implementation of court decisions.

4) The amount of forced money is decided based on legislation.

Looking at the provisions of Article 87 paragraph (1) of the UUPPLH, there are several elements, namely:

1) There is an illegal act;

2) There is pollution and/or environmental damage;

3) There is a loss to other people or the environment;

4) The existence of a business person and / or activity

Based on the discussion prior, the four elements above are actually actions that are against the law based due to errors. These consequences cause harm to other parties, and these actions are specifically in the environmental aspect. Unlike the illegal acts based on errors contained in Article 1365 of the Civil Code, this matter will be discussed in the next sub-chapter, considering that the perpetrators who commit acts against the law based on this error can be asked for their legal responsibilities.

According to Neuwenhius, as quoted by Siti Sundari Rangkuti, accountability is divided into 3 (three) groups, namely: ${ }^{26}$

1) Accountability based on errors (schuldaans prakelijheid), where errors are a basic element and must be proven so that one can be held accountable for losses suffered by another party. Another thing that is the principal of this type of accountability is that the defendant's fault is the responsibility of the plaintiff to prove it. It is as adopted in Indonesia as in Article 1365 of the Civil Code.

2) Accounts based on errors with the burden of proof reversed. In the Netherlands it is known as the "Schuldaansprakelijkheid met omerking

${ }^{26}$ Siti Sundari Rangkuti, Op.Cit., p. 11. 
van beweijslast". According to the mindset of this concept, the plaintiff is not burdened with the obligation to prove the defendant's fault, but the defendant must prove that he has sufficiently tried carefully so that it is not blamed for causing loss to the plaintiff. What is also contained in Article 1367 paragraph (5) of the Civil Code is the responsibilities of additional parties. For an instance if parents, guardians, school teachers and authorities prove that they cannot prevent acts to where they should be responsible".

3) Risk-based liability (risicoaansprakenlijkheid). This concept is the second type of accountability that is sharpened (verscherpkeaansprakenlijkheid). This type is stated in Article 1367 paragraph (3) and Article 1369 of the Civil Code, namely:

Article 1367 paragraph (3); "Employers and those who appoint others to represent their affairs are responsible for the losses incurred by their servants and subordinates in carrying out the work for which these people are used".

Article 1369: "The owner of a building is responsible for the loss caused by the collapse of the building in whole or in part if this occurs because of negligence in its maintenance or defects in development or its order".

\section{e. Actions Against Civil Law in Cases of Environmental Disputes}

The environmental legal disputes can be seen from various legal aspects, such as civil environmental law, administrative environmental law and environmental criminal law. Regarding to the dispute over civil environmental law, it is stated that the involvement of civil law relating to compensation claims are formulated in Article 87 of UUPPLH. The basics of the compensation claim are:

1) There is an illegal act;

2) There is pollution and/or environmental damage;

3) There is a loss to other people or the environment;

4) The existence of a business person and/or activity

Claims for compensation, as stated above can be done either through litigation or non-litigation. Substantially, the four basic aspects of the compensation claims above can be further explained as follows:

\section{1) There is an illegal act}

UUPPLH does not limit what is against the law but does not mean that it is unnecessary. For the actual legislators, what is meant by lawlessness here is an unlawful act as referred to in Article 1365 of the Civil Code, and its elements as the Decree of the January 31, 1919 Hoge in the case of Lindenbaum vs. Cohen, known as Drukkers Arrest:

a) The act violates applicable laws;

b) The act violates the rights of others; 
c) The act is contrary to decency;

d) The act is contrary to the legal obligations of the offender;

e) These actions conflict with obedience in society.

Associated with objects of action in the field of the environment, the specificity of the elements of lawlessness here includes, among others:

a) There is an act of pollution to the environment;

b) Pollution accompanied by environmental damage;

c) The existence of environmental damage.

Of the three elements above, what constitutes an unlawful act of environmental pollution is as formulated in Article 1 number 14 UUPPLH: "Environmental pollution is the entry or inclusion of living things, substances, energy, and/or other components into the environment by human activities so that it exceeds the prescribed environmental quality standards".

From the formulation, it becomes clear that acts against the law here lie by entering the environment through human activities, which exceeds the prescribed environmental quality standard. Thus, the act of entering happens through the executor's will. This proves the existence of error (schuld), namely the existence of a relationship between inner attitude (awareness of knowing) with real action (the actual action is done).

Associated with the elements of Article 1365 of the Civil Code, it becomes clear that illegal acts are carried out based on the existence of mistakes. These acts are either intentionally (because of their mistakes) entering living things, substances, energy, and/or other components into the environment, so that it exceeds the prescribed environmental quality standard. The impact is that the environment is damaged, and cannot be utilized by humans.

Rossa Agustina explained that the element "against the law" exists if it meets the following conditions: ${ }^{27}$

\section{a) Contrary to the subjective rights of others}

Breaking the subjective rights of others means violating the special authority granted by law to someone. The nature of the subjective right is a special authority granted by law to someone who obtains it for his benefit. One's subjective rights include:

a. Interest that has a high value towards the person concerned;

b. Direct recognition of the authority concerned by a statutory regulation;

c. A position of strong evidence in a case that might arise.

\section{b) Contrary to the legal obligations of the offender}

\footnotetext{
${ }^{27}$ Rossa Agustina, Op. Cit., p. 9.
} 
According to the prevailing view, the law is interpreted as an overall consisting of written and unwritten norms. What is meant by an act or omission that is contrary to the legal obligations of my civil servant is, a behavior that is contrary to a statutory provision? Whereas what is meant by law here are all legal regulations issued by the competent agency and have an exit power.

\section{c) Contrary to decency}

The rules of decency are defined as social norms in society, insofar as community members accept them as/in the form of unwritten legal regulations. As a consideration, the case between Lindenbaum vs. Cohen where Cohen's actions were considered contrary to moral conduct when he persuaded Lindenbaum's employees to divulge the secrets of his company.

\section{d) Contrary to compliance, thoroughness and caution}

In this sense, humans must have tolerance with their environment and fellow human beings so that they are not only concerned with personal interests but also the interests of others so that acting must be by propriety, thoroughness and caution in the community. This includes acts that are contrary to propriety, such as (a) actions that harm other people without proper interest, and (b) useless actions that cause harm to others based on normal thinking need to be considered. Relating to mistakes, Rosa Agustina explained the element of error in an act does not differ greatly from the element of violating the law. This element emphasizes the combination of the two elements above where the action fulfills the elements against the law, including intentional or negligence. An error is used to state that someone is declared responsible for making compensation.

\section{2) There are damages incurred for other people and the environment}

As stated in Article 1365 of the Civil Code, the special form of damage arising in the field of the environment is solely for individuals or legal entities. However, according to UUPPLH the community can not use the general public, namely the destruction of the environment, its utilization. It then becomes the reason in environmental law with the legal standing for environmental organizations to demand compensation.

From the aspect of civil law, the element of compensation determines the obligation of the perpetrators of illegal acts to pay compensation. Although there is no further regulation regarding the compensation, Article 1371 paragraph (2) of the Civil Code at least provides a few guidelines by stating, "Also this compensation is assessed according to the position and ability of both parties and according to circumstances". Even in paragraph (2), it is affirmed: "In judging one another, the Judge must pay attention to the severity 
of insults, as well as the rank, position and ability of both parties, and on the circumstances".

\section{3) The existence of parties that can be held accountable}

As already been stated, according to Article 1365 of the Civil Code, the parties that can be accounted for to replace loss are those who caused damage as an impact of their mistakes. It is clearly confirmed in Article 87 paragraph (1) UUPPLH:

"Every person in charge of a business and/or activity which violates the law in the form of environmental pollution and/or damage that causes harm to other people or the environment, must pay compensation and/or take certain actions". Thus, it becomes apparent in the formulation of Article 87 paragraph (1) that every person in charge of the business and/or activity that commits "violation of law" has the liability to replace damages in the case of environmental pollution.

It is interesting to point out, in some cases of Indonesia's environmental pollution; many parties are involved both directly and indirectly because it needs to emphasise the entrepreneurs' responsibility. The fact it, some cases are carried out by companies which proven to be responsible. However, the same situation does not automatically apply in an individual case.

\section{4) Form of liability}

Article 1365 of the Civil Code has stated that the form of liability is compensation. Although in Article 87 paragraph (1) UUPPLH has been determined to pay compensation and/or carry out specific actions, it can be concluded that this form of liability is the result of an accountability process in the environmental dispute resolution process.

There is a new form of compensation in environmental law, wherein Article 87 paragraph (3) UUPPLH stated that Courts could determine the payment of forced money every day of delay during the court decisions are executed. Even in paragraph (4), the amount of forced money has been determined. Thus, compensation is an obligation that must be fulfilled, and if it is not fulfilled strict action will be taken based on the court's decision.

\section{5) There is a causal relationship}

In the case of environmental pollution, a cause-effect relationship needs to be clarified between the action that occurred and the loss experienced. This relationship can be seen in UUPPLH. In the formulation of Article 87 paragraph (1), there is a strict sentence, such as causing harm to other people or the environment. Affirmation of this sentence has been clearly understood because the result of causing harm to others can be interpreted as a relationship with the actions taken. It can be concluded that the consequences are in forms 
of loss and damage to the environment. From the perspective of Article 1365 of the Civil Code, the element of error is determined between the actions and consequences that occur. To explain this cause and effect, there are two theories of causation or causality, namely: ${ }^{28}$

\section{1) The Conditio Sine Qua Non Theory of von Buri}

The essence of this teaching is each problem, which is a condition for the emergence of a result, is a cause of the effect. According to Von Buri, mistakes can be made to all parties that result in losses.

\section{2) The Adaequate Veroorzaking Theory of von Kries}

This theory teaches that actions as causes of consequences are actions that are balanced with consequences. The basis for determining balanced actions is a proper calculation, that is, according to common sense, it can be expected that these actions can cause certain consequences.

Starting from what was stated above; it becomes clear that all elements that are the requirements of the principle of liability are based on acts against the law and cause damages to other parties. As referred in Article 1365 of the Civil Code, it can also be used to explain the existence of an element of lawlessness with an error and causing harm as referred to in Article 87 paragraph (1) UUPPLH. Therefore, the UUPPLH adheres to the principle of liability based on specific errors, while the liability based on mistakes in Article 1365 of the Civil Code is more general.

\section{f. Compensation Through the Civil Defense Account in the Case of Botak Mountain}

It has become a legal reason in civil law cases that if a party incurs a loss, it is a result of an unlawful act due to an error committed by another person. Thus, parties who feel disadvantaged have the right to request compensation for what they experience.

The case of environmental pollution due to illegal mining of gold mining by local people and migrants on Botak Mountain in Buru Island, Maluku Province has now caused massive loss to the community, not only at this time but also in the future. The loss does not involve damage to the environment, yet the loss of natural resources values owned by the community and regional governments that have been depleted for the benefit of certain parties. Until the end of 2013, there have been several conflicts between local occupation,

\footnotetext{
${ }^{28}$ Abdul Latif, Hukum Administrasi Dalam Tindak Pidana Korupsi, cet,II, Jakarta: Kencana, (2016), p. 325.
} 
landowners and holders of communal rights (besickingrecht) of the Buru Island indigenous people with seekers or gold hunters.

The ban on mining activities had been carried out several times, both by the Regional Government and law enforcement officials, but it was never efficient. Currently, mining activities cannot be controlled, and the use of chemicals such as mercury and cyanide to help the process of discovery of gold continue to be used, without taking into account the impact. Most of the rivers around Buru Island have been contaminated. The contents of mercury and cyanide have reached $0.0529 \mathrm{mg} /$ litre on Waepo River, $0.0049 \mathrm{mg} / \mathrm{liter}$ on Suket River, $0.0089 \mathrm{mg} / \mathrm{liter}$ in Kali Nekat, $0.006 \mathrm{mg} / \mathrm{liter}$ in Wamsait River, $0.0042 \mathrm{mg} / \mathrm{liter}$ in Anahoni River and $0.0463 \mathrm{mg} / \mathrm{liter}$ in Hulu Kali Wamsait, which is known for the resident's source of water. Even from the legal materials obtained, it shows a photo of some sago fields and community land that is dry and cannot be used anymore. ${ }^{29}$

It is in mind of how the next result would be if this fails to overcome. It would be catastrophic to the people of Buru Island, Maluku Province. ${ }^{30}$ Judging from the process of social interaction, there has been competition between miners who are not cooperative with the Government and law enforcement officials. These miners tend to be controlled by migrant community groups. Illegal miners also returned to the mining site after the withdrawal of security guards, it seems as if the community ignored national authorities and law.

Against this problem, in December 2013 after receiving the blessing of the Minister of Energy and Mineral Resources, the Governor of Maluku ordered Buru Regency to close the mining site which had been running for approximately two years. From several public reports, it is estimated that these illegal gold miners have used approximately 50,000 drums with 1000 barrels (drums) containing cyanide chemicals Each drum (drum) on average can produce 50 gr of gold per/day, while the use of cyanide chemicals can produce up to $200 \mathrm{gr}$ of gold per/day. These data were reported by the Indonesian Gold Mining Association or Asosiasi Pertambangan Emas Rakyat Indonesia (ASPIRI). Additionally, the report estimated that there are around 2.5 million tons of gold on Botak Mountain in Buru Island. Thus, it can be estimated that the production value can reach 1.1 trillion Indonesian Rupiah per/day. ${ }^{31}$

If this alone is taken as a serious issue, then the people's lack of rights including indigenous peoples on Buru Island where the impact is felt on the river and coast damages as a result of environmental pollution, both on land and water and coastal areas have made it into an ultimate urgency.

\footnotetext{
${ }^{29}$ Daily PagiSiwalima, edition January 17, 2013.

${ }^{30}$ Kilas Maluku, Mengerikan, Beginilah Dampak Aktivitas Tambang di Gunung Botak, Edition May 22, 2015.

${ }^{31}$ Kompas.com, accessed on Monday, October 8, 2012.
} 
The situation above shows that people will always have the right to prosecute their loss, not to mention as a result of the environmental damages. Hence, with the contamination of chemical waste, especially the use of mercury and cyanide in gold mining to the quality of the water itself which is a primary necessity. Moreover, contaminated river water that has spread to the coastal areas immediately disturbs the areas of fishers.

The explanation of Article 87 UUPPLH stated that the miners could be held accountable in civil law (privaatrechtelijkmiliuerecht) through the principle of absolute liability (strick liability-risicoaansprakelijkheid). This absolute obligation arises immediately at the time of the act, without questioning the defendant's mistake. ${ }^{32}$

In the case, as happened in Buru Island, the application to claim compensation from environmental pollution through a lawsuit is one of the best alternatives, including the restoration of the environment. This claim is based on the principle of the existence of an illegal act (onrechtmatigedaad) as referred to in Article 1365 of the Civil Code. ${ }^{33}$ Thus in a case like this, it can be understood that the principle of civil liability in the damaged environment is based on the existence of an unlawful act in terms of Article 1365 of the Civil Code. On the other hand, the responsibility mechanism and procedures tend to use the model of absolute responsibility as confirmed in Article 87 UUPPLH.

The compensation approach as a form of claim is reasonable since it was a case of pollution and environmental destruction due to the use of chemicals in Buru Island. Regarding the use of chemicals, it is certainly not an issue of a civil matter, because it is based on absolute accountability, it will be more effective if it is prosecuted through criminal law. The basis of compensation claims in civil cases is loss that is experienced by the community from the damage and pollution contaminating their living environment because mining is carried out illegally.

The code of accountability

Civil law can be grouped into two parts, namely (a) contractual and; (b) accountability for illegal acts. Next explained:

The difference between the two responsibilities above is whether or not the legal relationship has an agreement. If there is an agreement, then the responsibility is contractual. Whereas there is no agreement, but one party has issues with the other party, then the aggrieved party can be an adverse party because the party is responsible is based on illegal acts. Therefore, liability is related to the existence of a law in the field of civil law, where certain defendants are asked to claim the party. Claims occur as a consequence of a

\footnotetext{
${ }^{32}$ Siti Sundari Rangkuti (I), Op.Cit., pp. 281-282.

${ }^{33}$ Rossa Agustina, Op.Cit., p. 4.
} 
reaction suffered by another party (the plaintiff). Starting from what was stated above; it became clear that the claim for compensation through civil liability could be carried out because of an illegal act based on an error which resulted in the community feeling disadvantaged. It is said that there are illegal acts based on errors, because:

1) There are people (individuals/or groups of people who are organized) doing mining, in this case, the people from outside Maluku and also from Buru Island and its surroundings;

2) The existence of mining activities carried out without permission, both from the community owner of customary rights and the local government so that these deeds are deemed illegal because they are contrary to the rights of the community;

3) From the aspect of propriety, actions that are against the law are carried out by mistake, because they do know the consequences of mining actions that harm others.

The People Buru Island applies for civil liability claims to parties that cause harm or are represented to community groups. They provided clear legal standing. It can be based on Article 88 UUPPLH, namely that:

"Every person whose actions, business, and/or activities use B3, produce and/or manage B3 waste, and/or that pose a serious threat to the environment are responsible for the losses incurred without the need to prove the element of error".

Regarding the affirmation of the provisions of this article, in environmental law cases, the principle of strict liability is known. Indeed, this principle is only implemented in certain types of situations (casuistic), and it includes the situation of a strict liability application, such as extra-hazardous activities which according to Article 88 covers environmental disputes due to business activities:

a. Large and important impacts on the environment;

b. Using hazardous and toxic substances (B-3) and or;

c. Produces B-3 waste

The purpose of applying the principle of strict liability in this environmental case is solely to fulfill a sense of justice in society, because in UUPPLH, it is explained in a general explanation that "in some activities involving certain types of resources, responsibility arises absolutely to destroyers and/or polluters at the time of the occurrence of damage and/or pollution of the environment whose arrangements are regulated in the relevant laws and regulations". In addition to carrying out a civil liability claim, it also needs to be followed by accountability by using the principle of strict liability.

The purpose of the application for accountability was to fulfil justice in the community. Ahmad Santosa emphasised that "The purpose of 
implementing the principle of absolute accountability is: to fulfil a sense of justice; run with the complexity of the development of technology, natural resources and the environment; and encourage high-risk business entities to internalise the social costs that can arise due to their activities". ${ }^{34}$ On the contrary, civil liability is intended to provide legal protection for victims of environmental pollution by filing an environmental dispute in the public court. It needs to be emphasized that environmental dispute resolution is defined as a claim for compensation based on illegal actions in the field of civil environmental law. According to Article 84 UUPPLH:

1) Settlement of environmental disputes can be taken through a court or outside the court.

2) The choice of environmental dispute resolution is carried out voluntarily by the parties to the dispute.

3) A claim through a court can only be reached if an attempt to resolve a dispute outside the court of justice is declared unsuccessful by one of the parties to the dispute.

There are interesting things from the prosecution process as stated in Article 84 above, where the positive law does not prohibit the settlement path as priorities to the disputing parties, whether it is selected by the court or outside the court. However, from the aspect of civil law based on Article 1365 of the Civil Code, victims of environmental pollution can immediately file a lawsuit to the court, even though they are aware that they will face a complicated process, even taking a long time, as well as outside the court , because Article 84 paragraph (3) affirms that "a claim through a court can only be taken if an attempt to resolve a dispute outside the chosen court is declared unsuccessful by one of the parties to the dispute". Furthermore, the substance of the filed claim in demanding compensation in civil liability in the environmental field is in need to discuss.

Referring to Article 87 UUPPLH, the compensation claim will be obtained if it fulfils the elements, (a) the existence of the person in charge of the activity/business; (b) there is an unlawful act; (c) the occurrence of pollution and environmental damage, which results in causing harm to other people or the environment. Thus, "acts against the law" (onrechtmatigedaad) here must be the basis of an environmental dispute claim, namely in the form of pollution and or environmental destruction. It needs to be emphasized, because not all acts against the law can be used as a basis/reason to be brought to court.

Pollution or environmental damage here is the entry or inclusion of substances, energy, and/or other components into the environment by human

\footnotetext{
${ }^{34}$ Mas Achmad Santosa et al, Penerapan Atas Tanggung Jawab Mutlak (Strict Liability) di Bidang Lingkungan Hidup, Jakarta: ICEL, (1997), p. 59.
} 
activities. These damages exceed the environmental quality standards as stipulated. ${ }^{35}$ Environmental pollution is a reason for a lawsuit in an environmental dispute. Pollution and/or environmental destruction are objects of environmental disputes. Based on Article 87 of Law No. 32 of 2009 and Article 1365 of the Civil Code, civil claims against the existence of environmental damage or pollution will be fulfilled because the liability based on an error means that the plaintiff must be able to prove the defendant's fault for compensation. ${ }^{36}$

Noting the level of pollution and environmental damage that is now occurring around Botak Mountain, it is time for the community to claim compensation to the parties, especially the illegal gold miners coordinated by several community business groups. Therefore, Article 87 UUPPLH is a procedural provision, while Article 1365 of the Civil Code is a substantial provision that needs to be fulfilled by those who feel disadvantaged.

Siahaan explained that proving the existence of an error is not easy because it must first be proven the causal relationship (causal) between the act of pollution or environmental damage with the loss experienced by the victim. $\mathrm{He}$ admitted proof of environmental aspects is indeed difficult because analyzing the act of pollution requires an explanation that is scientific, technical and special so that if the scale is broad (transfrontier) and serious, it is necessary to prove cause and effect with difficult risks.

In sum, ordinary accountability does not seem to reflect a sense of justice. Victims experience complicated situation in the journey of maintaining general accountability because the victims have suffered a loss that will not be restored by just proving any errors. ${ }^{37}$

\section{Conclusion}

From the case of environmental destruction and pollution that occurred in Buru Island, Maluku Province, the principle of civil liability or known as "liability" or "aanspraakelijkheid" can be used to prosecute parties that cause harm to the community. The reason for using the principle of accountability is because, in the case of environmental destruction and pollution that occurs on Botak Mountain of Buru Island, the perpetrators use chemicals consisting mercury and cyanide to process minerals in rapid golf mining. If Article 87

\footnotetext{
35 appeal of Article 1 number 14 UUPPLH while environmental destruction is the activity of people who cause direct or indirect changes to the physical, chemical andor biological characteristics of the environment so that they exceed the standard criteria for environmental damage (Article 1 point 16

${ }^{36}$ Siti Sundari Rangkuti (II), Op. Cit., pp. 269-271.

${ }^{37}$ Siahaan, Hukum Lingkungan, Jakarta: Pancuran Alam, (2006), pp. 274-275.
} 
paragraph (1) UUPPLH is executed, then the pollution perpetrators are qualified to the following elements: (a) have committed an unlawful act; (b) resulting in environmental pollution and/or damage; (c) cause harm to other people or the environment; and (d) there are business and/or activity responsible persons. Furthermore, to be able to fulfill the demands for compensation according to civil law, Article 1365 of the Civil Code requires the existence of onrechtmatigedaad elements or acts against the law, which include: (a) the act is against the law; (b) the action is based on error; (c) the result of the action arises a damage; and (d) there is a causal relationship between actions and losses.

Article 1365 of the Civil Code ensures the fulfilment of rights, like the existing loss is a result of others' errors. Acts against the law here outline the existence of rights and obligation when a person commits an act, either an error or negligence or also injuring another person. Unlawful acts based on the apparent errors of this case are: (a) mining activities carried out without permission, both from the voter community and the local government, so that these deeds are illegal, because they are contrary to the rights of the community, and (b) those acts that are against the law are carried out by mistake, because they do know the consequences of mining actions that harm others.

\section{A. Books}

\section{Bibliography}

Achmad, Santosa Mas. (1997). Penerapan Atas Tanggung Jawab Mutlak (Strict Liability) di Bidang Lingkungan Hidup. Jakarta: ICEL.

Brown Lester R. (1992). Dua Puluh Dua Segi Masalah Kependudukan. Jakarta: Yayasan Obor Indonesia.

Campbell, Black Henry. (1991).Black'a Law Dictionary. St. Paul, Minn, West Publishing Co.

Chief M. (2000). Black's Dictionary. St Paul Minessota: Mwest Group.

Darus, Badruzalman Mariam. (2001). KompilasiHukumPerikatan. Bandung: Citra Aditya Bakti.

Helmi. (2012). Hukum Perizinan Lingkungan Hidup. Jakarta: Sinar Grafika. Lutfi,Yazid. (1999). Penyelesaian Sengketa Lingkungan (Environmetal Dispute Resolution). Surabaya: Airlangga University Press - Yayasan Adikarya IKAPI - Ford Foundation.

Mahmud, Marzuki Peter. (2005). Hukum Lingkungan dan Kebijaksanaan Lingkungan Nasional. Surabaya: Airlangga University Press.

Mahmud, Marzuki Peter. (2008). Penelitian Hukum. Jakarta: Kencana Prenada Media Group.

Moegni, Djojodirjo. (1979). Perbuatan Melawan Hukum. Jakarta: Pradnya Paramita. 
Rossa, Agustina. (2012). Hukum Perikatan (Law Obligation), Seri UnsurUnsur Penyusun Bangunan Negara Hukum. Denpasar Bali: Pustaka Larasan.

Siahaan. (2006). Hukum Lingkungan. Jakarta: Pancuran Alam.

Subekti. (2001). Hukum Perjanjian. Jakarta: Intermasa.

Theory, Hutchinson. (2002). Researching and Writing in Law. Australia: Lawbook Co, Pyrmon NST.

\section{B. Journal and Article}

La Ode Angga, "Alternatif Penyelesaian Sengketa Lingkungan Hidup di Luar Pengadilan (Non Litigasi)", Jurnal Ius (Jurnal Kajian Hukum dan Keadilan, 6 (2), (2018), https://doi.org/10.29303/ius.v6i2.548.

La Ode Angga, "Prinsip Kehati-Hatian Dalam Peraturan Daerah Rencana Tata Ruang Wilayah Provinsi Maluku Di Bidang Pengawasan dan Evaluasi Berbasis Keberlanjutan Lingkungan Hidup",Universitas Brawijaya Dissertation, (2015).

Rangkuti Siti Sundari, "Inovasi Hukum Lingkungan: Dari Ius Constitutum ke Ius Constituendum", Speech of Inauguration of Professors said at the Senate Meeting of Airlangga University, Faculty of Law, Airlangga University, Saturday, May 11, 1991.

\section{World Wide Web}

Kilas Maluku, Mengerikan, Beginilah Dampak Aktivitas Tambang di Gunung Botak, Edition May 22, 2015.

http://www.artikellingkunganhidup.com, accessed on February 18, 2019

5N.H.T Siahaan, Hukum Lingkungan dan Ekologi Pembangunan, Jakarta: Erlangga, 2004.

Kompas.com, Monday, October 8, 2012

HarianPagi, Ambon Express, Edition October 10, 2012.

HarianPagi "Siwalima", EditionJanuary 17, 2013.

http://www.mongabay.co.id/2018/06/10/petaka-tambang-emas-di-pulauburu/, accessed on August 14, 2018.

\section{Legislations}

Code of Civil law.

Indonesia Constitution 1945.

Republic of Indonesia Law No. 32 on 2009.

Republic of Indonesia Law No. 4 on 2009. 
